\title{
HUBUNGAN PENGETAHUAN DAN SIKAP TENTANG PENGELOLAAN SAMPAH DENGAN PERILAKU PEMBUANGAN SAMPAH
}

\author{
Iin Kristanti*
}

\begin{abstract}
ABSTRAK
Jumlah timbunan sampah Kabupaten Cirebon mencapai 4839,31 m²/hari sedangkan yang dapat terangkut hanya $3353,64 \mathrm{~m}^{3} /$ hari atau yang tidak terangkut sebanyak $1.636 \mathrm{~m}^{3} /$ hari. Kondisi ini terjadi antara lain karena kemampuan pemerintah Kabupaten Cirebon untuk pengadaan sarana prasarana yang dapat melayani kebutuhan yang ada masih terbatas. Oleh karena itu perlu dipikirkan pengurangan volume sampah melalui dari sumbernya. Hasil pengamatan yang penulis lakukan pada tanggal 2 Januari 2016 di Desa Jagapura Lor Kecamatan Gegesik Kabupaten Cirebon masih ditemukan warga masyarakat yang mengolah sampah dengan caradibakar, membuang sampahnya di kali dan dibiarkan terbuka di halaman atau kebun sehingga menimbulkan bau dan kemungkinan terjadinya perkembangbiakan lalat, tikus, dan nyamuk selain itu dapat menjadi sumber pengotoran tanah, sumber pengotoran air dan pencemaran udara. Penelitian ini bertujuan untuk menganalisis tentang hubungan pengetahuan dan sikap tentang pengelolaan sampah dengan Perilaku Pembuangan sampah di Desa Jagapura Lor Kecamatan Gegesik Kabupaten Cirebon. Jenis penelitian yang digunakan adalah bersifat deskriptif analitik dengan metode cross sectional. Yang menjadi sampel dalam penelitian ini adalah kepala keluarga yang mengelola sampah yang berjumlah 89 orang dengan menggunakan teknik wawancara dan observasi dan analisis data menggunakan uji chi square. Penelitian ini menggunakan uji statistik chi square. Hasil penelitian menunjukan ada hubungan antara pengetahuan (pvalue $=0,013$ ) dan sikap (pvalue $=0,037$ ) tentang pengelolaan sampah dengan pembuangan sampah di desa Jagapura Lor kecamatan Gegesik kabupaten Cirebon tahun 2016.

Kata Kunci : Pengetahuan dan sikap, Perilaku Pembuangan Sampah
\end{abstract}

\begin{abstract}
The amount of waste Cirebon reach $4839.31 \mathrm{~m}^{3} /$ day while that can be transported only $3353.64 \mathrm{~m}^{3} / \mathrm{day}$ or were not transported as much as $1,636 \mathrm{~m}^{3} / \mathrm{day}$. This condition occurs partly because the government's ability to procure Cirebon infrastructure that can serve the needs are still limited. Therefore, it needs to consider a reduction in the volume of waste through source. The observation that the author did on January 2, 2016 in Jagapura Lor Gegesik Subdistrict Cirebon still found citizens who process waste by burning, throwing trash at times and left open in the yard or garden so that cause odor and the possibility of proliferation of flies, mice and mosquitoes but it can be a source of ground fouling, fouling water sources and air pollution. This study aimed to analyze the influence of knowledge and attitudes about waste management garbage disposal Behavior in Jagapura Lor Gegesik District of Cirebon. This type of research is descriptive analytic with cross sectional method. The sample in this study is the head of the family who manage waste totaling 89 people by using interview and observation techniques. This study uses a statistical test Chi Square. The results showed no relationship between knowledge $(\mathrm{p}$ value $=0.013)$ and attitude $(\mathrm{p}$ value $=0.037)$ on waste management with waste disposal in rural districts Gegesik Jagapura Lor Cirebon regency in 2016.
\end{abstract}

Keywords : Knowledge and attitudes, Garbage Disposal Behavior 


\section{PENDAHULUAN}

Kesehatan lingkungan adalah suatu keadaan atau kondisi lingkungan hidup bebas dari bahaya dan risiko minimal untuk terjadinya infeksi silang, dan masalah kesehatan dan masalah keselamatan kerja sebagai akibat dari pencemaran. ${ }^{1}$

Pencemaran lingkungan hidup adalah masuknya atau dimasukkannya makhluk hidup, zat, energi, dan atau komponen lain ke dalam lingkungan hidup oleh kegiatan manusia sehingga kualitasnya turun sampai ke tingkat tertentu yang menyebabkan lingkungan hidup tidak dapat berfungsi dengan baik. Salah satu penyebab pencemaran lingkungan dikenal dengan sebutan sampah. Sampah adalah sisa suatu usaha atau kegiatan yang mengandung bahan berbahaya dan atau beracun yang karena sifat dan konsentrasinya dan atau jumlahnya, baik secara langsung maupun tidak langsung dapat mencemarkan dan merusak lingkungan hidup, kesehatan, kelangsungan hidup manusia serta makhluk hidup lain. ${ }^{1}$

Sampah merupakan salah satu permasalahan kompleks yang dihadapi, baik oleh negaranegara berkembang maupun negara-negara maju di dunia. Masalah sampah merupakan masalah yang umum dan telah menjadi fenomena universal di berbagai negara belahan dunia manapun, dengan titik perbedaannya terletak pada seberapa banyak sampah yang dihasilkan. ${ }^{2}$

Berbicara mengenai timbunan sampah perkotaan di suatu negara, pastinya tidak terlepas dari tiga faktor utama yang mempengaruhi yaitu: tingkat konsumsi, tingkat pendapatan, dan kepadatan penduduk di daerah perkotaan. Tingkat konsumsi masyarakat dianggap sangat mempengaruhi timbunan sampah pada suatu wilayah atau Negara. Pola hidup konsumtif yang digambarkan dalam tingginya tingkat konsumsi, mendorong orang tidak hanya memenuhi kebutuhan primer, namun juga mengejar kebutuhan sekunder maupun kebutuhan tersiernya. Hal ini, pada akhirnya, merubah jenis dan jumlah sampah yang dihasilkan oleh individu setiap harinya. ${ }^{3}$

Pada kota-kota di Indonesia, persoalan sampah sekarang ini menjadi isu penting bahkan menjadi fenomena sosial, mengapa hal ini terjadi dikarenakan begitu banyak masalah sampah yang sesegera mungkin harus ditangani. Belajar dari kasus Bantar Gebang, Bojong, Leuwigajah dan beberapa kota lainnya, terindikasikan bahwa sampah yang tidak dikelola/ditangani dengan baik menjadi penyebab terjadinya pencemaran air, tanah, udara dan bahkan sampai timbul kerawanan sosial di tengah masyarakat. ${ }^{4}$

Permasalahan persampahan yang sudah mengemuka secara nasional, secara umum didominasi oleh wilayah perkotaan yang memiliki keterbatasan lahan TPA (Tempat Pembuangan Akhir) sehingga dampaknya tidak saja terhadap pencemaran lingkungan dan timbulnya friksi antar kota tetapi bahkan sudah menelan korban meninggal (146 di TPA Leuwigajah dan 6 orang di TPA Bantar Gebang). ${ }^{5}$

Penanganan dan pengendalian akan menjadi semakin kompleks dan rumit dengan semakin kompleksnya jenis maupun komposisi dari sampah sejalan dengan semakin majunya kebudayaan. Perkembangan kota yang pesat menyebabkan bertambahnya jumlah penduduk kota. Salah satu dampak akibat laju pertumbuhan penduduk adalah meningkatnya volume sampah yang diproduksi. ${ }^{5}$

Di dalam pengelolaan sampah perkotaan, masalah utama kota-kota di Indonesia adalah terbatasnya kemampuan pemerintah di daerah dalam menghadapi masalah pengumpulan dan pembuangan sampah yang terus meningkat. Dari total jumlah penduduk Indonesia yaitu 232,7 juta penduduk yang terlayani hanya 130,3 juta penduduk atau sekitar $56 \%$. Pada umumnya hanya sedikit sampah dapat dikumpulkan dan dibuang dengan cara yang benar sehingga penanganan sampah di Indonesia sangat kurang dan diperkirakan akan semakin memburuk pada masa mendatang akibat semakin bertambahnya volume timbunan sampah dan juga keanekaragaman kandungan yang terdapat di dalamnya. ${ }^{5}$

Berdasarkan data Dinas Kebersihan Kabupaten Cirebon tahun 2014, jumlah timbunan sampah kabupaten mencapai 4839,31 m²hari sedangkan yang dapat terangkut hanya 3353,64 
$\mathrm{m}^{3} /$ hari atau yang tidak terangkut sebanyak $1.636 \mathrm{~m}^{3} / \mathrm{hari}$. Kondisi ini terjadi antara lain karena kemampuan pemerintah Kabupaten Cirebon untuk pengadaan sarana prasarana yang dapat melayani kebutuhan yang ada masih terbatas. Oleh karena itu perlu dipikirkan pengurangan volume sampah melalui dari sumbernya.

Hasil penelitian Fitrul Kamal tahun 2009 tentang Hubungan antara Tingkat Pengetahuan dan Sikap Ibu Rumah Tangga tentang Pengelolaan Sampah dengan Perilaku Pembuangan Sampah pada Masyarakat Sekitar Sungai Beringin, menyatakan tidak ada hubungan antara tingkat pengetahuan dengan perilaku pembuangan sampah ( $p$-value 0,0129). Sedangkan sikap berhubungan perilaku pembuangan sampah ( $p$-value 0,037$){ }^{5}$

Hasil pengamatan yang penulis lakukan pada tanggal 2 Januari 2016 di Desa Jagapura Lor Kecamatan Gegesik Kabupaten Cirebon masih ditemukan warga masyarakat yang mengolah sampah dengan cara dibakar, membuang sampahnya di kali dan dibiarkan terbuka di halaman atau kebun sehingga menimbulkan bau dan kemungkinan terjadinya perkembangbiakan lalat, tikus, dan nyamuk selain itu dapat menjadi sumber pengotoran tanah, air dan pencemaran udara. Data yang diperoleh tahun 2015, bila dibandingkan dengan desa Jagapura kulon dan Jagapura Wetan yang timbulan sampah hanya di bawah nilai 5 ton/hari, timbulan sampah di desa Jagapura Lor Kecamatan Gegesik Kabupaten Cirebon, yaitu 8 ton/hari. ${ }^{6}$

Tujuan penelitian ini untuk mengetahui hubungan pengetahuan dan sikap tentang pengelolaan sampah dengan perilaku pembuangan sampah di Desa Jagapura Lor Kecamatan Gegesik Kabupaten Cirebon 2016.

\section{METODE PENELITIAN}

Penelitian ini bersifat deskriptif analitik dengan pendekatan cross sectional. Variabel independen dalam penelitian ini adalah pengetahuan dan sikap masyarakat tentang pengelolaan sampah. Variabel dependen dalam penelitian ini adalah perilaku pembuangan sampah. Populasi dalam penelitian ini adalah Kepala Keluarga yang mengelola sampah di Desa Jagapura Lor Kecamatan Gegesik berjumlah 823 kepala keluarga. Jumlah sampel penelitian ini 89 kepala keluarga. Teknik pengambilan sampel menggunakan metode accidental sampling. Instrument pengumpulan data yang digunakan dalam penelitian ini adalah lembar wawancara/kuesioner dan lembar obsevasi. Analisa bivariat menggunakan analisa chi square.

\section{HASIL PENELITIAN}

\section{Aspek Pengetahuan Responden}

Tabel 1. Distribusi Responden Berdasarkan Pengetahuan Di Desa Jagapura Lor Kabupaten Cirebon 2016

\begin{tabular}{|c|c|c|c|}
\hline No & Aspek Pengetahuan & $\mathrm{n}$ & Persentase (\%) \\
\hline 1 & Kurang & 9 & 10,1 \\
\hline 2 & Cukup & 11 & 12,4 \\
\hline 3 & Baik & 69 & 77,5 \\
\hline \multicolumn{2}{|c|}{ Jumlah } & 89 & 100 \\
\hline
\end{tabular}

Pada tabel 1 dapat diketahui dari 89 KK, yang memiliki pengetahuan baik tentang pengelolaan sampah sebanyak 69 responden $(77,5 \%)$. 


\section{Aspek Sikap Responden}

Tabel 2. Distribusi Responden Berdasarkan Sikap Di Desa Jagapura Lor Kabupaten Cirebon 2016

\begin{tabular}{clcc}
\hline No & Aspek Sikap & $\mathrm{n}$ & Persentase (\%) \\
\hline 1 & Negatif & 37 & 41,6 \\
2 & Positif & 52 & 58,4 \\
\hline & Jumlah & 89 & 100 \\
\hline
\end{tabular}

Pada tabel 2 diatas dapat diketahui dari $89 \mathrm{KK}$, yang memiliki sikap positif tentang pengelolaan sampah sebanyak 52 responden $(58,4 \%)$.

\section{Perilaku Pembuangan Sampah}

Tabel 3. Distribusi Responden Berdasarkan Perilaku Di Desa Jagapura Lor Kabupaten Cirebon 2016

\begin{tabular}{cccc}
\hline No & $\begin{array}{c}\text { Perilaku Pembuangan } \\
\text { sampah }\end{array}$ & $\mathrm{n}$ & Persentase (\%) \\
\hline 1 & Kurang baik & 64 & 72 \\
2 & Baik & 25 & 28 \\
\hline & Jumlah & 89 & 100 \\
\hline
\end{tabular}

Berdasarkan tabel 3 dapat diketahui bahwa sebagian besar responden kurang baik dalam hal pembuangan sampah yaitu sebanyak 64 responden (72\%).

\section{Hubungan Pengetahuan dengan Pengelolaan sampah}

Tabel 4. Hubungan Pengetahuan dengan Perilaku Pembuangan sampah Di Desa Jagapura Lor Kabupaten Cirebon 2016

\begin{tabular}{|c|c|c|c|c|c|c|c|}
\hline \multirow{3}{*}{ Pengetahuan } & \multicolumn{4}{|c|}{ Pembuangan sampah } & \multirow{2}{*}{\multicolumn{2}{|c|}{ Total }} & \multirow{3}{*}{$p$ value } \\
\hline & \multicolumn{2}{|c|}{ Kurang baik } & \multicolumn{2}{|c|}{ Baik } & & & \\
\hline & $\mathrm{n}$ & $\%$ & $\mathrm{n}$ & $\%$ & $\mathrm{n}$ & $\%$ & \\
\hline Kurang & 6 & 66,7 & 3 & 33,3 & 9 & 100 & 0,013 \\
\hline cukup & 8 & 72,7 & 3 & 27,3 & 11 & 100 & \\
\hline Baik & 50 & 72,5 & 19 & 27,5 & 69 & 100 & \\
\hline Total & 64 & 72 & 25 & 28 & 89 & 100 & \\
\hline
\end{tabular}

Berdasarkan tabel 4 diketahui bahwa dari 9 responden yang pengetahuannya kurang baik mempunyai perilaku pembuangan sampah yang kurang baik sebanyak $66,7 \%$. Hasil uji statistik chi square diperoleh nilai $\mathrm{p}$ value $=0,013$ berarti ada hubungan yang bermakna antara pengetahuan dengan Perilaku Pembuangan sampah di Desa Jagapura Lor Kecamatan Gegesik Kabupaten Cirebon tahun 2016.

\section{Hubungan Sikap dengan Perilaku Pembuangan sampah}

Berdasarkan tabel 5, dari 37 responden yang sikapnya negatif mempunyai perilaku pembuangan sampah yang kurang baik sebanyak 56,8\%. Hasil uji statistik chi square diperoleh nilai $\mathrm{p}$ value $=0,0371$, berarti ada hubungan yang bermakna antara sikap dengan pengelolaan sampah di Desa Jagapura Lor Kecamatan Gegesik Kabupaten Cirebon tahun 2016. 
Tabel 5. Hubungan Sikap dengan Perilaku Pembuangan sampah Di Desa Jagapura Lor Kabupaten Cirebon 2016

\begin{tabular}{|c|c|c|c|c|c|c|c|}
\hline \multirow{3}{*}{ Sikap } & \multicolumn{4}{|c|}{ Pembuangan sampah } & \multirow{2}{*}{\multicolumn{2}{|c|}{ Total }} & \multirow{3}{*}{$p$ value } \\
\hline & \multicolumn{2}{|c|}{ Kurang baik } & & \multirow{2}{*}{$\frac{\text { Baik }}{\%}$} & & & \\
\hline & $\mathrm{n}$ & $\%$ & $\mathrm{n}$ & & $\mathrm{n}$ & $\%$ & \\
\hline Negatif & 21 & 56,8 & 16 & 43,2 & 37 & 100 & 0,037 \\
\hline Positif & 43 & 82,7 & 9 & 17,3 & 52 & 100 & \\
\hline Total & 64 & 72 & 25 & 28 & 89 & 100 & \\
\hline
\end{tabular}

\section{PEMBAHASAN}

\section{Hubungan Pengetahuan dengan Perilaku Pembuangan Sampah}

Berdasarkan tabel 4 dari 9 responden yang pengetahuannya kurang baik dengan perilaku pembuangan sampahnya kurang baik sebanyak $66,7 \%$. Hasil uji statistik chi square diperoleh nilai $\mathrm{p}$ value $=0,013$ berarti ada hubungan yang bermakna antara pengetahuan dengan Perilaku Pembuangan sampah di Desa Jagapura Lor Kecamatan Gegesik Kabupaten Cirebon tahun 2016. Hal ini sejalan dengan hasil penelitian Fitrul Kamal yang menyatakan bahwa Pengetahuan responden memiliki hubungan dengan perilaku pembuangan sampah. ${ }^{5}$ Pengetahuan atau kognitif merupakan domain yang sangat penting untuk terbentuknya praktek atau tindakan seseorang. Salah satu unsur yang diperlukan agar dapat berbuat sesuatu adalah pengetahuan dan jika kita menghendaki sesuatu dapat dikerjakan dengan terusmenerus maka diperlukan pengetahuan yang positif tentang apa yang harus dikerjakan, dengan kata lain perilaku atau tindakan yang dilandasi pengetahuan akan lebih langgeng dibanding praktek atau tindakan yang tanpa didasari pengetahuan dan tingkat pengetahuan seseorang mempengaruhi praktek individu, semakin tinggi pengetahuan seseorang semakin tinggi kesadaran untuk berperan serta.

Hal ini dikarenakan masyarakat yang berpengetahuan tinggi belum tentu melakukan suatu tindakan, misalnya masyarakat di desa Jagapura lor mengetahui manfaat dan tujuan dari pengelolaan sampah, tetapi mereka tidak mau melakukannya, sebaliknya masyarakat yang tidak mengetahui manfaat dan tujuan dari pengelolaan sampah mereka mau melakukan suatu tindakan dalam pembuangan sampah tersebut, jadi suatu perilaku atau tindakan seseorang tergantung pada diri orang tersebut, selain itu juga dikarenakan ibu rumah tangga beranggapan bahwa tidak ada manfaatnya melakukan pembuangan sampah dengan benar, hal ini dikarenakan tidak tersedianya fasilitas dalam melakukan pengelolaan sampah seperti tempat penampungan sementara (TPS), tempat sampah dan pengangkutan sampah ke TPA (Tempat Pembuangan Akhir).

\section{Hubungan Sikap dengan Perilaku Pembuangan Sampah}

Berdasarkan tabel 5, dari 37 responden yang sikapnya negatif dengan perilaku pembuangan sampahnya kurang baik sebanyak 56,8\%. Hasil uji statistik chi square diperoleh nilai $\mathrm{p}$ value $=0,0371$, berarti ada hubungan yang bermakna antara sikap dengan pengelolaan sampah di Desa Jagapura Lor Kecamatan Gegesik Kabupaten Cirebon tahun 2016.

Hal ini sejalan dengan hasil penelitian Fitrul Kamal yang menyatakan bahwa sikap responden memiliki hubungan dengan perilaku pembuangan sampah. ${ }^{5}$ Sikap merupakan organisasi pendapat, keyakinan seseorang mengenai obyek atau situasi yang relatif ajeg, yang disertai adanya perasaan tertentu dan memberikan dasar kepada orang tesebut untuk membuat respon atau berperilaku dalam cara yang tertentu yang dipilihnya. Sikap merupakan reaksi atau respon seseorang terhadap suatu stimulus atau obyek yang diterimanya. Sikap itu belum merupakan suatu tindakan, akan tetapi merupakan predisposisi praktek (tindakan). Perilakuatau tindakan yaitu suatu sikap yang secara otomatis terwujud dalam suatu tindakan 
(overt behavior). Untuk terwujudnya sikap menjadi suatu tindakan nyata diperlukan fasilitas pendukung, antara lain fasilitas persampahan. ${ }^{7}$

Berdasarkan wawancara diketahui bahwa sikap responden terbentuk dari pengalamanpengalaman yang dialami sendiri atau orang-orang terdekat, seperti orang tua, saudara dan tetangga. Hal ini sesuai dengan pernyataan bahwa pembentukan dan perubahan sikap tidak terjadi dengan sendirinya. Lingkungan terdekat memiliki peranan penting dalam berperilaku. ${ }^{8}$

Ada hubungan antara sikap dan perilaku pembuangan sampah ini didukung oleh pengertian sikap yang menyatakan bahwa sikap merupakan kecenderungan untuk bertindak. Krech dan Crutch Fietd menyebutkan bahwa praktek atau tindakan seseorang akan diwarnai atau dilatarbelakangi oleh sikap yang ada pada orang yang bersangkutan. ${ }^{8}$

Hasil penelitian menunjukan bahwa responden yang memiliki sikap positif belum tentu melakukan perilaku pembuangan sampahnya dengan baik. Hal ini karena tidak tersedianya sarana dan prasarana berupa TPS, tenaga pengangkut sampah sehingga mereka berperilaku membuang sampahnya sesuai dengan kemampuan dan kebiasaan masyarakat setempat.

\section{SIMPULAN}

1. Sebagian besar pengetahuan responden baik sebanyak 69 responden $(55,5 \%)$.

2. Sebagian responden memiliki sikap positif sebanyak 52 responden $(58,4)$.

3. Sebagian besar responden kurang baik dalam hal pengelolaan sampah yaitu sebanyak 64 responden $(72 \%)$.

4. Ada hubungan antara tingkat pengetahuan tentang pengelolaan sampah dengan perilaku pembuangan sampah pada masyarakat di Desa Jagapura Lor Kecamatan Gegesik Kabupaten Cirebon tahun 2016.

5. Ada hubungan antara Sikap tentang pengelolaan sampah dengan perilaku pembuangan sampah pada masyarakat di Desa Jagapura Lor Kecamatan Gegesik Kabupaten Cirebon tahun 2016.

\section{SARAN}

Saran Praktis

1. Untuk masyarakat

Perlu adanya upaya untuk meningkatkan pengetahuan dan sikap tentang pengelolaan sampah dengan perilaku pembuangan sampah melalui penyuluhan dari pihak-pihak terkait, Dinas Kebersihan Kabupaten Cirebon.

2. Untuk Dinas Kebersihan

Diharapkan dinas kebersihan melakukan tanggung jawabnya di lapangan dengan cara lebih peka terhadap permasalahan kesehatan yang ada di masyarakat seperti pengelolaan sampah, selain itu Dinas Kebersihan juga bisa melakukan penyuluhan terhadap masyarakat mengenai pengelolaaan sampah.

Saran Teoritis

1. Untuk peneliti lain

Diharapkan melakukan penelitian dengan faktor-faktor yang lain yang belum diteliti.

2. Untuk Desa

Diharapkan menyediakan lahan secara swadaya untuk dijadikan TPS.

\section{DAFTAR PUSTAKA}

1. Depkes RI. Sistem Kesehatan Nasional. Jakarta;2009.

2. Budiman Chandra. Pengantar Kesehatan Lingkungan. Jakarta : EGC;2007.

3. Pramono. Studi Mengenai Komposisi Sampah Perkotaan di Negara-negara Berkembang. Jakarta: Jurnal FTSP Universitas Gunadarma; 2004. 
4. Anonim. Sampah Di Indonesia. [diakses tanggal 4 Januari 2016]. Diunduh dari : https://ooyi.wordpress.com.

5. Fitrul Kamal. Hubungan antara Tingkat Pengetahuan dan Sikap Ibu Rumah Tangga tentang Pengelolaan Sampah dengan Perilaku Pembuangan Sampah pada Masyarakat Sekitar Sungai Beringin Di RW 07 Kelurahan Wonosari Kecamatan Ngaliyan Kota Semarang Tahun 2009. Semarang: (Skripsi). Jurusan IKM, Fakultas Ilmu Keolahragaan. Universitas Negeri Semarang; 2009.

6. Puskesmas Gegesik Kabupaten Cirebon. Laporan Program Kesehatan Lingkungan. Cirebon; 2015.

7. Soekidjo Notoatmodjo \& Solita Sarwono. Pengantar Ilmu Perilaku Kesehatan. Jakarta: Badan Penerbit Kesehatan Masyarakat Fakultas Kesehatan Masyarakat Universitas Indonesia; 2010.

8. Solita Sarwono . Pengantar Ilmu Perilaku Kesehatan. Jakarta: Badan Penerbit Kesehatan Masyarakat. FKM UI; 2003. 